\title{
Removal of metals and metalloids from acidic mining lake (AML) using olive oil solid waste (OSW)
}

\author{
R. İlay ${ }^{1}$ - A. Baba ${ }^{2} \cdot$ Y. Kavdır ${ }^{1}$
}

Received: 10 May 2017 / Revised: 11 July 2018 / Accepted: 25 September 2018 / Published online: 3 October 2018

(C) Islamic Azad University (IAU) 2018

\begin{abstract}
The acidic mining lakes have low $\mathrm{pH}$ values and high metal and metalloid concentrations. In this study, the ability of lowcost olive oil solid waste (OSW) to remove $\mathrm{Al}, \mathrm{As}, \mathrm{Cd}, \mathrm{Fe}, \mathrm{B}$ and $\mathrm{Ti}$ ions from aqueous solutions in short term has been evaluated. Adsorption capacities $\left(\mathrm{mg} \mathrm{g}^{-1}\right)$ of OSW (1:5-1:10 w/v) were 764.06-411.75 for Al, 0.26 for As, 0.07-0.14 for $\mathrm{Cd}, 2181.5-2406.5$ for Fe, 23.70-82.50 for B and 0.12-0.0.34 for Ti. OSW addition increased acidic mine water (AMW) $\mathrm{pH}$ from 2.41 to 3.2 with $1: 5$ and from 2.41 to 2.7 to $1: 10$ mixing ratio, respectively, after $10 \mathrm{~min}$. The best gradual decrease has been observed with different ratio of OSW applications on B and Ti concentrations. OSW adsorbs $32.41 \%$ and $62.68 \%$ of B at the ratio of 1:5 and 1:10 and 55.29\% and 83.04\% of Ti at the ratio of 1:5 and 1:10 (OSW:AMW) mixtures, respectively. The results show that OSW has great potential for metal removal from acidic mine water.
\end{abstract}

Keywords Adsorption Olive oil solid waste $\cdot$ Heavy metal/metalloid $\cdot$ Acidic mine lake

\section{Introduction}

It is known that oxidation of sulfur bearing minerals is responsible for the formation of low $\mathrm{pH}$ waters. This event is typically observed in mining activities, which results in the formation of acid mine drainage (AMD) from underground galleries to surface waters or in the creation of acidic mining lakes (AML) within the surface depressions of abandoned open-pit mines. AMLs are commonly observed in the openpit coal mining sites in Central Europe and Northern America where lignite reserves are found close to ground surface. Hundreds of such AMLs are found in the Lusatia region of Germany (Friese et al. 1998; Yucel et al. 2014; Wisotzky and Obermann 2001; Karakas et al. 2003; Yucel and Baba 2013), and numerous researches have been conducted on their formations and characteristics (Blodau 2006; Evangelou 1998).

Editorial responsibility: Gobinath Ravindran.

\section{R. İlay}

rilay@comu.edu.tr

1 Soil Science and Plant Nutrition Department, Agricultural Faculty, Çanakkale Onsekiz Mart University, 17020 Çanakkale, Turkey

2 İzmir Institute of Technology, Geothermal Energy Research and Application Center, 35430 Gülbahçe, Urla, İzmir, Turkey
AMLs have low $\mathrm{pH}$ values and high metal and metalloid concentrations (Gunduz et al. 2007; Yucel et al. 2016). It has been previously reported that $\mathrm{pH}$ values ranged from 2 to 4 and electrical conductivity values reach up to $5000 \mu \mathrm{S}^{-1} \mathrm{~cm}$ (Yucel et al. 2014; Blodau 2006; Evangelou 1998). These low $\mathrm{pH}$ values cause elevated concentrations of metals/ metalloids and toxic elements such as $\mathrm{Cr}, \mathrm{Al}, \mathrm{Cd}, \mathrm{Mn}, \mathrm{As}$, $\mathrm{Zn}$ and Ni. Drainage water from AMLs can destruct downstream aquatic life. Besides degraded water quality, acidic mining lakes are also responsible for landslides by dissolving carbonate minerals in soil (Geller et al. 1998; Schultze and Geller 1996). There are number of AMLs in the Çan Coal District in Çanakkale, Turkey (Fig. 1). The area is rich in lignite, which is currently being utilized in a $2 \times 160 \mathrm{MW}$ capacity thermal power plant and in domestic heating of the surrounding residential areas. There are also numerous small-scale private companies that extract coal from a number of sites in the region. When the depression cones of these open pits are filled with surface and subsurface drainage, numerous AMLs with variable sizes are formed (Baba et al. 2009; Yucel et al. 2014). pH of these lakes are generally lower than 4 and accumulate metals such as $\mathrm{Al}, \mathrm{Fe}, \mathrm{Mn}$. The limnological and hydrogeochemical characteristics of AML (Gunduz and Baba 2008; Gunduz et al. 2007; Yucel and Baba 2013; Yucel et al. 2014) were studied in detail. Yucel and Baba (2016) reported that if sulfur content of a 

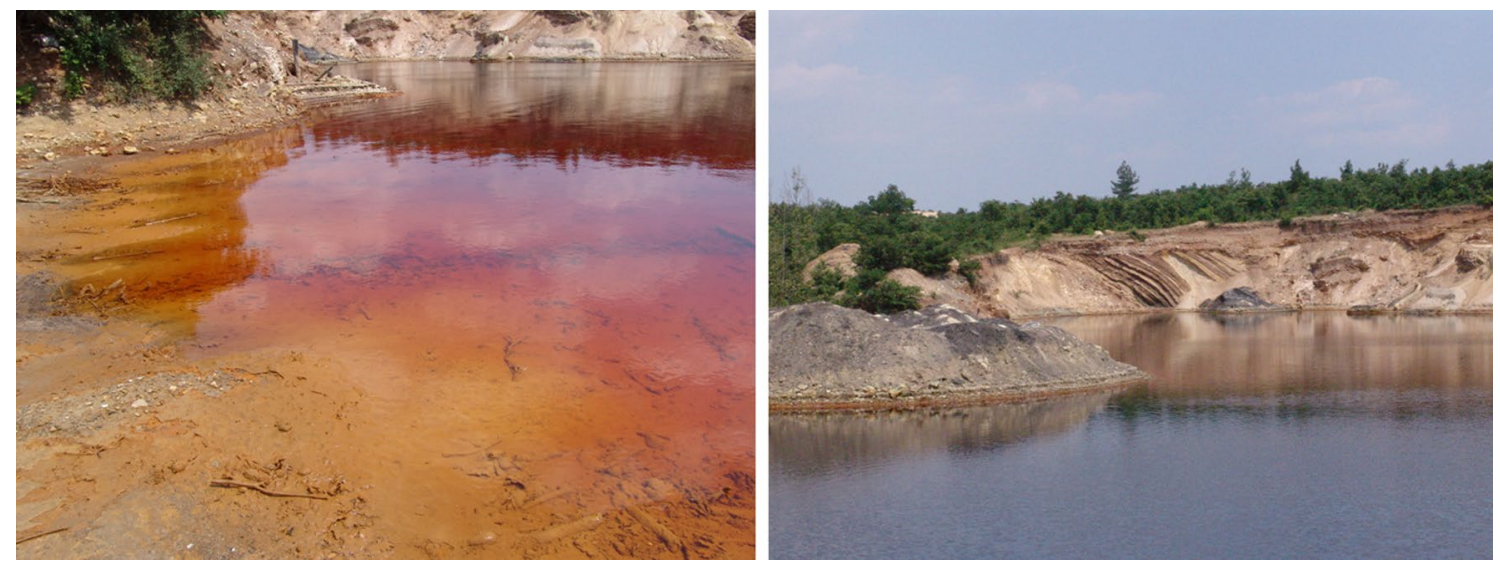

Fig. 1 Acidic mine lake in Biga Peninsula

rock $>0.3 \%$, it oxidizes rapidly and may produce AMD. The paste $\mathrm{pH}$ of the mine wastes was between 2.3 and 3.8, which were similar to $\mathrm{pH}$ value of AML water in the region.

Acidic mine lakes have brown reddish color caused by dissolution of iron hydroxides. If such lakes are not rehabilitated, they lead to contamination of surface and groundwater resources (Gunduz and Baba 2008). Reclamations of such lakes with current treatment technologies are expensive; therefore, there is an urge to find out other materials. Many technologies, including reverse osmosis and ion-exchange resin, have been used to remove heavy metals and harmful metalloids from aqueous solution. The most commonly used technology for active treatment is chemical neutralization. Liming is a common and effective treatment practice to neutralize acidity and precipitate heavy metals. However, this method of treatment becomes expensive due to the extensive period during which treatment is required (MEND 1994). The adsorbents can be mineral, organic, zeolites, industrial and agricultural by-products and wastes (Kurniawan et al. 2006). The lists of some materials that can be used as lowcost absorbents for metal and metalloid removal from aqueous solutions are summarized in Table 1.

Treatment of AMD by passive methods is grouped in four categories: anoxic limestone drain, neutralization, biosorption, bioreactors and wetland treatment. There are some criteria to select the best biosorption materials such as the treatment of AMD should not create environmental problems, materials used for AMD treatment should be renewable, materials should be readily available and material should be economic (Bechard 1993). Several ways to accumulate and bind pollutants by organic materials have been reported by Veglio and Beolchini (1997).

Turkey is an important olive producer and production of olive for oil extraction in 2015 was $1.3 \times 10^{6}$ tons in Turkey (TUIK 2015). Approximately $75 \%$ of trees were grown for olive oil production and $25 \%$ for table olive production in Turkey (TUIK 2015). About 26\% of Turkey's total olive production is produced from Marmara region (study area). Olive oil solid waste (OSW) is a by-product which can also cause storage problems. Little amounts of OSW are used as organic fertilizer (İlay et al. 2013), fodder, and additive in animal food. OSW can also be used as a low-cost adsorbent.

The use of agricultural and organic by-products in bioremediation of heavy metals is known as biosorption (Gupta et al. 1998, 2012a; Gupta and Saleh 2013). Biosorption of metals and metalloids by agricultural and industrial wastes is used in water treatment. Red mud (Nadaroglu et al. 2010) is largely produced from the alumina industry. De-oiled soya was used as an adsorbent for removal of toxic dyes from wastewater (Mittal et al. 2009, 2010). Hasan et al. (2000) reported that rubber-wood ash was good adsorbent for the $\mathrm{Ni}(\mathrm{II})$ cation from dilute solution. The maximum adsorption for nickel was $0.492 \mathrm{mmol} \mathrm{g}^{-1}$ at $\mathrm{pH} 5$ and $30^{\circ} \mathrm{C}$. Balarak et al. (2015) used canola residues to remove methylene blue from aqueous solution, and the maximum dye removal was obtained to be $97.5 \%$. Photocatalytic treatment can be used to reduce water pollution caused by dyes (Saravanan et al. 2013a, b). The photocatalytic activity of $\mathrm{ZnO}$ modified with CdO successfully degraded methylene blue under visible light (Saravanan et al. 2011, 2015). Martínez et al. (2006) used by-product of wine production for sorption of lead and cadmium from aqueous solutions. They reported that, at $\mathrm{pH}$ 5.5, maximum sorption capacities of grape stalk was 0.241 and $0.248 \mathrm{mmol} \mathrm{g}^{-1}$ for $\mathrm{Pb}(\mathrm{II})$ and $\mathrm{Cd}(\mathrm{II})$, respectively. $\mathrm{HCl}$ or EDTA solutions were successful to desorb lead from the grape stalks.

Amin et al. (2006) used rice husk to desorb arsenic from aqueous solution. Six grams of rice husk was mixed with $100 \mu \mathrm{g} \mathrm{L}^{-1}$ As containing solution at a $\mathrm{pH}$ range of 6.5-6.0. About 71-96\% desorption was observed with $\mathrm{KOH}$-treated rice husk. Besides modified cellulose materials, walnut hull was also good absorbent (Wang et al. 2009) for chromium 
Table 1 Metal/metalloids adsorption capacities for some low-cost adsorbents

\begin{tabular}{|c|c|c|c|}
\hline Material & Metal/metalloid & $\begin{array}{l}\text { Adsorption } \\
\text { capacities } \\
\left(\mathrm{mg} \mathrm{g}^{-1}\right)\end{array}$ & References \\
\hline Fly ash & B & 20.9 & Oztürk and Kavak (2005) \\
\hline Montmorillonite & $\mathrm{Cu}(\mathrm{II})$ & 3.0 & Abollino et al. (2003) \\
\hline Cocoa shells & $\mathrm{Pb}(\mathrm{II})$ & 6.2 & Meunier et al. (2003) \\
\hline Cork wastes & $\mathrm{Pb}(\mathrm{II})$ & 13.46 & López-mesas et al. (2011) \\
\hline Organophilic bentonite & $\mathrm{Cd}(\mathrm{II})$ & 2.8 & Andini et al. (2006) \\
\hline Hazelnut shell & $\mathrm{Ni}(\mathrm{II})$ & 10.1 & Demirbas et al. (2002) \\
\hline Tobacco dust & $\mathrm{Zn}(\mathrm{II})$ & 25.1 & Qi and Aldrich (2008) \\
\hline Peanut hulls & $\mathrm{Cu}(\mathrm{II})$ & 65.6 & Periasamy and Namasivayam (1996) \\
\hline Orange peel (citrus reticulate) & $\mathrm{Ni}(\mathrm{II})$ & 80.0 & Ajmal et al. (2000) \\
\hline \multirow[t]{3}{*}{ Grape stalk waste } & $\mathrm{Ni}(\mathrm{II})$ & 10.6 & Villaescusa et al. (2004) \\
\hline & $\mathrm{Cu}(\mathrm{II})$ & 10.1 & \\
\hline & $\mathrm{Cd}(\mathrm{II})$ & $0.24 *$ & Martinez et al. (2006) \\
\hline Coffee beans & $\mathrm{Cd}(\mathrm{II})$ & $0.058^{*}$ & Kaikake et al. (2007) \\
\hline \multirow[t]{2}{*}{ Grape stalk } & $\mathrm{Cu}(\mathrm{II})$ & 42.92 & Escudero et al. (2008) \\
\hline & $\mathrm{Ni}(\mathrm{II})$ & 38.31 & \\
\hline Apple residues & $\mathrm{Cd}(\mathrm{II})$ & 0.158 & Lee et al. (1998) \\
\hline Tobacco (dust cultural waste) & $\mathrm{Pb}(\mathrm{II})$ & 39.6 & Qi and Aldrich (2008) \\
\hline Sugar beet pulp & $\mathrm{Pb}(\mathrm{II})$ & 73.8 & Reddad et al. (2003) \\
\hline Olive pomace & $\mathrm{Cd}(\mathrm{II})$ & 0.030 & Martín-Lara et al. (2008) \\
\hline Tree bark & $\mathrm{Cu}(\mathrm{II})$ & 21.6 & Gaballah and Kilbertus (1998) \\
\hline Banana peel & $\mathrm{Cu}(\mathrm{II})$ & 0.075 & Kurniawan et al. (2006) \\
\hline Olive cake & $\mathrm{Cd}(\mathrm{II})$ & 65.35 & Al-Anber and Matouq (2008) \\
\hline Tea factory waste & $\mathrm{Cr}(\mathrm{VI})$ & 54.65 & Malkoc and Nuhoglu (2007) \\
\hline Grape bagasse & $\mathrm{Cd}(\mathrm{II})$ & 0.479 & Farinella et al. (2007) \\
\hline Palm tree leaves & $\mathrm{Zn}(\mathrm{II})$ & 14.7 & Abu Al-Rub (2006) \\
\hline Rubber-wood & & $0.492 *$ & Hasan et al. (2000) \\
\hline Cotton cellulose & $\mathrm{B}(\mathrm{III})$ & 11.3 & Liu et al. (2007) \\
\hline Apple residue & $\mathrm{Cu}(\mathrm{II})$ & 0.170 & Lee et al. (1998) \\
\hline Rice bran & $\mathrm{Zn}(\mathrm{II})$ & 14.17 & Wang et al. 2006 \\
\hline \multirow[t]{2}{*}{ Brewery waste } & $\mathrm{Pb}(\mathrm{II})$ & $33.1-1656$ & Can and Jianlong (2008) \\
\hline & $\operatorname{Ag}(\mathrm{I})$ & $17.3-864$ & \\
\hline Carrot residue & $\mathrm{Cu}(\mathrm{II})$ & 0.515 & Nasernejad et al. (2005) \\
\hline \multirow[t]{2}{*}{ Crab shell } & $\mathrm{Cu}(\mathrm{II})$ & 243.9 & Vijayaraghavan et al. (2006) \\
\hline & $\mathrm{Co}(\mathrm{II})$ & 322.6 & \\
\hline \multirow[t]{3}{*}{ Maize cob and husk } & $\mathrm{Zn}(\mathrm{II})$ & 495.9 & Iqwe et al. (2005) \\
\hline & $\mathrm{Pb}(\mathrm{II})$ & 456.7 & \\
\hline & $\mathrm{Cd}(\mathrm{II})$ & 493.7 & \\
\hline Olive pomace & $\mathrm{Cu}(\mathrm{II})$ & $0.180^{*}$ & Martín-Lara et al. (2008) \\
\hline Active carbon from oat hulls & As & $1.57-3.09$ & Chuang et al. (2005) \\
\hline \multirow[t]{6}{*}{ Olive solid waste (OSW) } & $\mathrm{Al}(\mathrm{III})$ & $764.05-411.75$ & This study \\
\hline & As & 0.26 & \\
\hline & $\mathrm{Cd}(\mathrm{II})$ & $0.079-0.142$ & \\
\hline & $\mathrm{Fe}$ & $2181.5-3406.5$ & \\
\hline & B & $23.70-82.50$ & \\
\hline & $\mathrm{Ti}$ & $0.128-0.348$ & \\
\hline
\end{tabular}

*mmol g-1 
(VI). Optimum $\mathrm{pH}$ for removal was 1.0, while chromium (VI) removal was $97.3 \%$ (Wang et al. 2009). The removal increased with adsorbent concentration and the decrease in adsorbate concentration. Gharaibeh et al. (1998) reported that olive oil by-products were efficient for zinc and lead removal from aqueous solutions. Removal of heavy metals and metalloids from contaminated water is very important for environmental health (Weng and Huang 2004). Conventional technologies for the removal of heavy metal such as chemical precipitation, membrane separation, reverse osmosis, adsorption and emulsion per traction technology (Zhou et al. 1993; Naiya et al. 2009; Ali 2010, 2012; Ali et al. 2012; Gupta et al. 2011, 2012b, 2013). Saravanan et al. (2016) suggested that PANI/ZnO nanocomposite can be used for environmental remediation. Many methods have been studied to develop much more cheaper and effective technique for removal of metals and metalloids from wastewater and adsorption was the most effective method for removal of heavy metal if combined with appropriate regeneration steps (Naiya et al. 2009; Khan et al. 2011; Ali et al. 2016, 2017).

The aim of this study is to investigate the possible use of olive oil solid waste (OSW) as a low-cost and reachable adsorbent for the removal of toxic metals and metalloids from acidic mine lakes which can be seen in different part of world such as Biga Peninsula.

\section{Materials and methods}

\section{Study area}

The Çan Coal District is located in Biga Peninsula in North Western Turkey. It is located about $100 \mathrm{~km}$ away from Çanakkale. The Çan Coal District has been in operation since 1980s, and lignites are being extracted in the region. Acidic lakes can be seen around this region where agriculture especially olive and olive oil productions are an important part of economy. As a result, high amount of olive oil waste are generated that can cause storage problems. Paleozoic-aged metamorphic rocks are the basement of the study area. Volcanic rocks are altered and fractured due to the effects of active faults in the region (Fig. 2). Many industrial metals and some precious metals have been detected in the altered volcanic rocks (Baba and Gunduz 2010; Baba et al. 2009).

\section{Methods}

$100 \mathrm{~mL}$ sample was taken from AML water for heavy metals and metalloids analysis. AML samples were filtered through $0.45-\mu \mathrm{m}$ filter paper and stored in refrigerator at $4{ }^{\circ} \mathrm{C}$. $0.5 \mathrm{~N} \mathrm{HNO}_{3}$ was added to samples to reduce sample $\mathrm{pH}$ below 2 and analyzed by inductively coupled plasma-mass spectroscopy technique (Agilent 7500ce Octopole Reaction System (ORS) ICP-MS). Some chemical analysis results of AMW are shown in Table 2. Olive oil solid waste (OSW) has been obtained from olive oil factory in Çanakkale, and some analysis results of OSW (İlay et al. 2013) are presented in Table 3. Total carbon and nitrogen contents of OSW were determined by Leco CN elemental analyzer (Kirsten 1983). Dry ashing technique was used to determine macro- and micro-element contents of OSW and analyzed by ICP-OES (Wolf et al. 2003). Total phenolic compounds (TPC) of OSW was determined by using the Folin-Ciocalteu reagent and expressed as gallic acid equivalents (Lesage-Meessen et al. 2001). EC and $\mathrm{pH}$ of OSW was determined in 1:5 OSW: water mixtures using $\mathrm{EC}$ and $\mathrm{pH}$ meter. OSW samples were sieved through 4-mm screen opening, subsamples were taken and mixed with acidic mine water (AMW) at rates of 1:5 (20 g OSW:100 $\mathrm{ml}$ AMW) and 1:10 w/v (20 g OSW:200 ml AMW) with five replicates. $\mathrm{pH}$ of OSW and OSW-AMW mixture was determined using an Orion 420A $\mathrm{pH}$ meter. Samples were mixed with glass stirrer, and initial $\mathrm{pH}$ was determined after $10 \mathrm{~min}$. The tops of the beakers were covered with parafilm to prevent evaporation of water from samples then shaked for $19.5 \mathrm{~h}$ at $100 \mathrm{rpm}$ with rotational shaker (Heidolph-unimax). Samples were removed from shaker and $\mathrm{pH}$ readings were repeated (1st reading). Samples were shaked at $100 \mathrm{rpm}$, and $\mathrm{pH}$ readings were repeated every hour for 5 times $(2,3,4,5,6$. readings). Before ICP analysis, samples were filtered through Whatman No: 2 filter paper and stored at cooler at $4{ }^{\circ} \mathrm{C}$. Results of $\mathrm{pH}$ values after shakings are presented in Fig. 3. All these measurements were conducted at $25^{\circ} \mathrm{C}$ laboratory temperature.

Surface area measurements were performed on Quantachrome Quadrasorb SI surface area analyzer. The samples were out-gassed for $3 \mathrm{~h}$ under nitrogen prior to adsorption measurement. The specific surface area of OSW was determined by applying the BET method. OSW was ground with grinder, and sieved to $0.5 \mathrm{~mm}$ particle size and sample weight was $0.34 \mathrm{~g}$.

Heavy metals and metalloid absorptions of OSW at 1:5 and 1:10 AMW have been calculated according to Eq. (1)

$q=\left[\left(C_{i}-C_{f}\right) * V\right] / W$

where $q=$ (amount of adsorbate, adsorbed in $\mathrm{mg}$ )/(amount of adsorbent used for adsorption in $\mathrm{g}$ ). $C_{i}$ is the initial concentration of heavy metals and metalloid $\left(\mathrm{mg} \mathrm{L}^{-1}\right) ; C_{f}$ is final heavy metals and metalloid concentrations of solution $\left(\mathrm{mg} \mathrm{L}^{-1}\right) ; V$ is final total volume in the reactor $(\mathrm{L}) ; W$ is the amount of OSW used for biosorption test $(\mathrm{g})(*$ density of OSW was $0.8 \mathrm{~g} \mathrm{~cm}^{-3}$ ).

SPSS 17 package program has been used for statistical analysis. Differences among treatments were determined by ANOVA; comparisons were made by Post Hoc Test. 


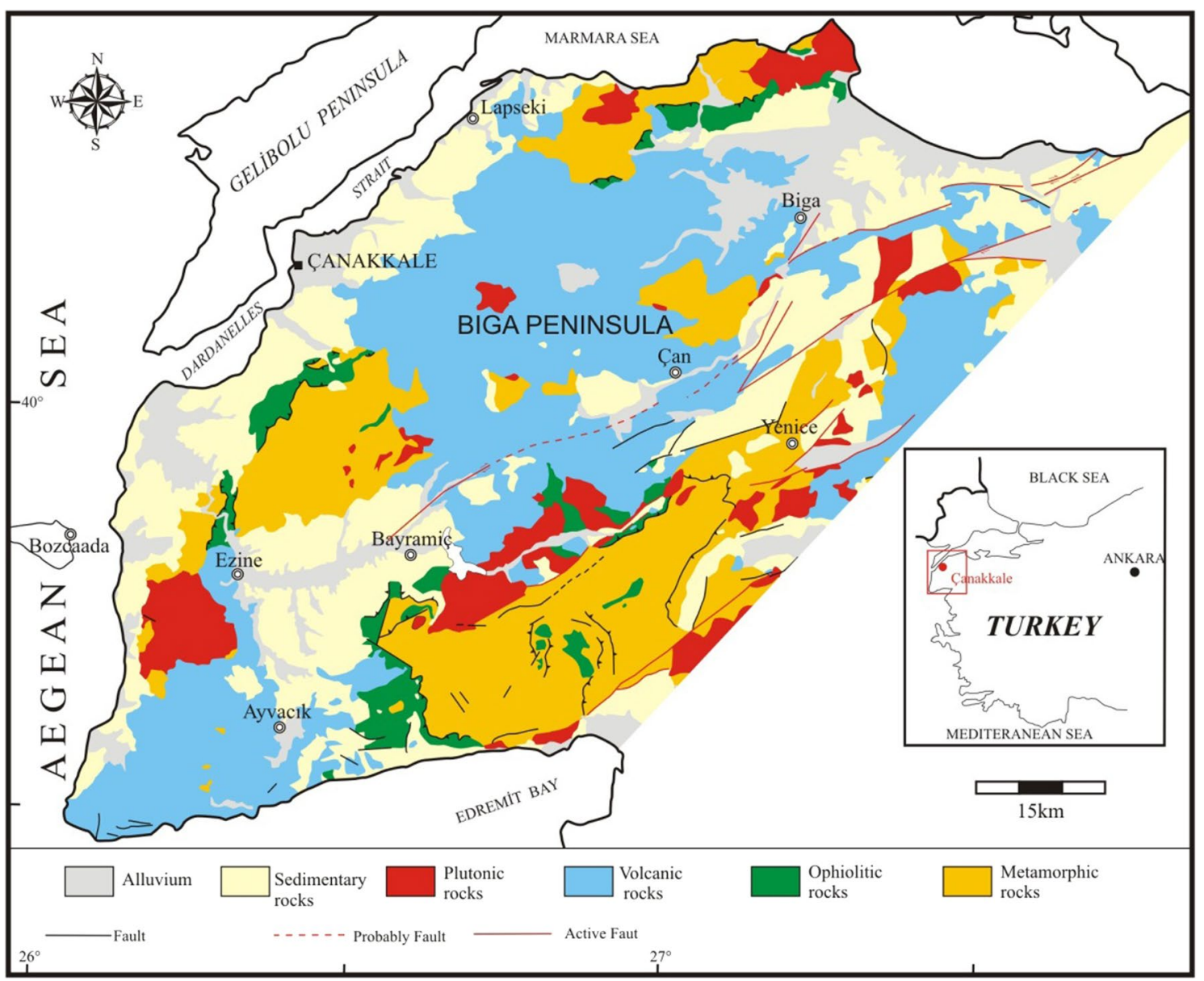

Fig. 2 Geological map of Biga Peninsula (Baba and Gunduz 2010, modified from General Directorate of Mineral Research, Exploration 2002)

\section{Results and discussion}

OSW has low pH (5.7), high Fe (1243.91 $\left.\mathrm{mg} \mathrm{kg}^{-1}\right)$ content and surface area of OSW was $0.545 \mathrm{~m}^{2} \mathrm{~g}^{-1}$ (Table 3). Descriptive statistical results are presented in Tables 4 and 5 . The results of heavy metals and metalloids concentrations after treatment of AMW are presented in Figs. 4, 5 and 6. AMLs have low $\mathrm{pH}$ values and high metal and metalloid concentrations (Gunduz et al. 2007; Yucel et al. 2016).

Addition of OSW to AMW increased $\mathrm{pH}$ from 2.41 to 3.2 with $1: 5$ and from 2.41 to 2.7 with $1: 10$ mixing ratio, respectively, after $10 \mathrm{~min}$ (Fig. 3). The increase in $\mathrm{pH}$ can be caused by either adsorption of acidic metals by OSW or release of basic elements from OSW. OSW applications reduced $\mathrm{Al}, \mathrm{As}, \mathrm{Cd}, \mathrm{Fe}, \mathrm{B}$ and $\mathrm{Ti}$ concentrations in AMW which resulted with the increase in mixture $\mathrm{pH}$. Increasing $\mathrm{pH}$ in AMW:OSW mixtures reduced most of the metals and metalloid concentrations except As. Al and Fe concentration reduced with 1:5 OSW which had higher solution $\mathrm{pH}$. B, $\mathrm{Ti}$ and $\mathrm{Cd}$ concentrations reduced in AMW:OSW mixtures compared to AMW alone (pH:2.41, Fig. 3).
Heavy metals and metalloid adsorption capacities of OSW are presented in Table 6. Except Al, all cations were effectively adsorbed by 1:10 (OSW:AMW) mixture. Al concentration of AMW reduced from 273 to $150.75 \mathrm{mg} \mathrm{L}^{-1}$ when it was mixed with 1:5 (OSW:AMW) mixture (Fig. 4a). OSW: AMW (1:5) treatment reduced Al concentration of AMW about 45\%, while 1:10 (OSW:AMW) treatment reduced $13 \%$ (Fig. $4 a$ ).

On the other hand, 1:5 (OSW:AMW) mixture had no significant effect on As reduction from AMW (Table 4 and Fig. 4b). 1:10 (OSW:AMW) mixture application reduced As concentration of AMW about $22 \%$ compared to initial value $(p<0.05)$.

OSW application dramatically reduced Fe concentrations of AMW (Fig. 5a). Average initial Fe concentration was $411 \mathrm{mg} \mathrm{L}^{-1}$, and it reduced to $61.95 \mathrm{mg} \mathrm{L}^{-1}$ with OSW addition (1:5). OSW treatments reduced Fe concentrations $84.92 \%$ and $73.67 \%$ with $1: 5$ and $1: 10$ (OSW:AMW) mixtures, respectively (Fig. 5a). Iron content of OSW was originally higher than those of AMW (Tables 2 and 3). When AMW amount increased from 1:5 to 1:10 (OSW:AMW) 
Table 2 Chemical properties of AMW

Table 3 Chemical properties of the OSW (Illay et al. 2013)

\begin{tabular}{ll}
\hline Parameters & Value \\
\hline $\mathrm{pH}$ & $5.7 \pm 0.04$ \\
$\mathrm{EC}\left(\mu \mathrm{S} \mathrm{cm}^{-1}\right)$ & $822 \pm 2$ \\
$\mathrm{~N}(\%)$ & $1.12 \pm 0.06$ \\
$\mathrm{P}(\%)$ & $0.04 \pm 0.00$ \\
$\mathrm{~K}(\%)$ & $0.57 \pm 0.00$ \\
$\mathrm{Ca}(\%)$ & $0.5 \pm 0.02$ \\
$\mathrm{Mg}(\%)$ & $0.06 \pm 0.00$ \\
$\mathrm{~B}\left(\mathrm{mg} \mathrm{kg}{ }^{-1}\right)$ & $16.9 \pm 0.55$ \\
$\mathrm{Fe}\left(\mathrm{mg} \mathrm{kg}^{-1}\right)$ & $1243.91 \pm 75.61$ \\
$\mathrm{Mn}\left(\mathrm{mg} \mathrm{kg}^{-1}\right)$ & $32.75 \pm 1.99$ \\
$\mathrm{Zn}\left(\mathrm{mg} \mathrm{kg}^{-1}\right)$ & $17.34 \pm 3.15$ \\
$\mathrm{C}(\%)$ & $49.1 \pm 0.75$ \\
$\mathrm{TPC}\left(\mathrm{mg} \mathrm{kg}^{-1}\right)$ & $1.20 \pm 0.01$ \\
$\mathrm{C} / \mathrm{N}$ & $43.8 \pm 1.86$ \\
$\mathrm{BET} \mathrm{surface}$ area $\left(\mathrm{m}^{2} \mathrm{~g}^{-1}\right)$ & 0.545 \\
\hline
\end{tabular}

TPC total phenolic compounds

mixture, soluble Fe of OSW released into the water. As a result 1:10 (OSW:AMW) mixture has higher Fe content compared to 1:5 (Fig. 5a).
OSW treatments reduced Cd contents significantly $(p<0.05)$ by $38.67 \%$ and $38.48 \%$ with $1: 5$ and $1: 10$ (OSW:AMW) mixtures, respectively (Table 5 and Fig. $5 b$ ). Gupta et al. (2006) used an industrial solid waste of sugar industry called "The bagasse fly ash" and removed $90 \%$ of $\mathrm{Cd}$ and $\mathrm{Ni}$ in 60 and $80 \mathrm{~min}$, respectively, under the batch test conditions. Gupta et al. (2006) also studied influences of solution $\mathrm{pH}$, adsorbent dose, adsorbate concentration, temperature, particle size, etc., on the removal of $\mathrm{Cd}$ and $\mathrm{Ni}$. Maximum adsorption of $\mathrm{Cd}$ and $\mathrm{Ni}$ observed when concentrations were 14 and $12 \mathrm{mg} \mathrm{L}^{-1}$ and at a $\mathrm{pH}$ value of 6.0 and 6.5. Martín-Lara et al. (2008) reported that Cd absorption capacity of OSW was $0.030 \mathrm{mmol} \mathrm{g}^{-1}$. In this study, $\mathrm{Cd}$ absorption capacity of OSW was 0.07 and $0.14 \mathrm{mg} \mathrm{g}^{-1}$ for 1:5 and 1:10 (OSW:AMW) mixtures, respectively. There were statistical differences $(p<0.05)$ of $\mathrm{Cd}$ contents among OSW treated and untreated AMW; however, no significant differences have been observed between ratios (Table 5 and Fig. 5b).

Agricultural by-products bind heavy metals by adsorption, chelation and ion exchange (Gardea-Torresdey et al. 1996; Sun and Shi, 1998). Iqwe et al. (2005), investigated that the adsorption of $\mathrm{Pb}^{2+}, \mathrm{Cd}^{2+}$ and $\mathrm{Zn}^{2+}$ ions from solutions by unmodified and modified maize cob and husk. Maximum adsorption occurred at 495.9, 456.7 and $493.7 \mathrm{mg} \mathrm{g}^{-1}$ for $\mathrm{Zn}^{2+}, \mathrm{Pb}^{2+}$ and $\mathrm{Cd}^{2+}$ ion, respectively, without modification.

$\mathrm{B}$ and Ti concentrations were lower in 1:10 (OSW:AMW) mixture than those in 1:5 ratio (Fig. 6a, b). Liu et al. (2007) reported that with higher $\mathrm{pH}$, there was lower removal of boron by cotton cellulose. Therefore, increasing AMW resulted in lower solution $\mathrm{pH}$ and lower $\mathrm{B}$ and Ti removal. Instead of increasing sorbent amount, perhaps solution $\mathrm{pH}$ can be increased to enhance removal capacity of OSW.

The best gradual decrease has been observed with different ratio of OSW applications on B and Ti concentrations (Fig. 6b). OSW adsorbs $32.41 \%$ and $62.68 \%$ of B at the ratio of 1:5 and 1:10, respectively. OSW adsorbs 55.29\% and $83.04 \%$ of Ti at the ratio of 1:5 and 1:10 (OSW:AMW) mixtures, respectively (Fig. 6b).

Several organic materials used to treat AMW according to local availability such as composts produced from cow manure, sawdust, straw (Vile and Wieder 1993). They reported that AMW quality in compost wetlands is improved by filtration of colloidal materials and adsorption of metals by the organic matrix. In general, biologically mediated $\mathrm{Fe}$ (II) reduction occurred and caused alkalinity (Vile and Wieder 1993).

Agricultural waste and other agricultural by-products have been used to remove heavy metals from aqueous medium (Kelly-Vargas et al. 2012; Hegazi 2013; Kadirvelu et al. 2001; Hamza et al. 2013). Carrot residues were 


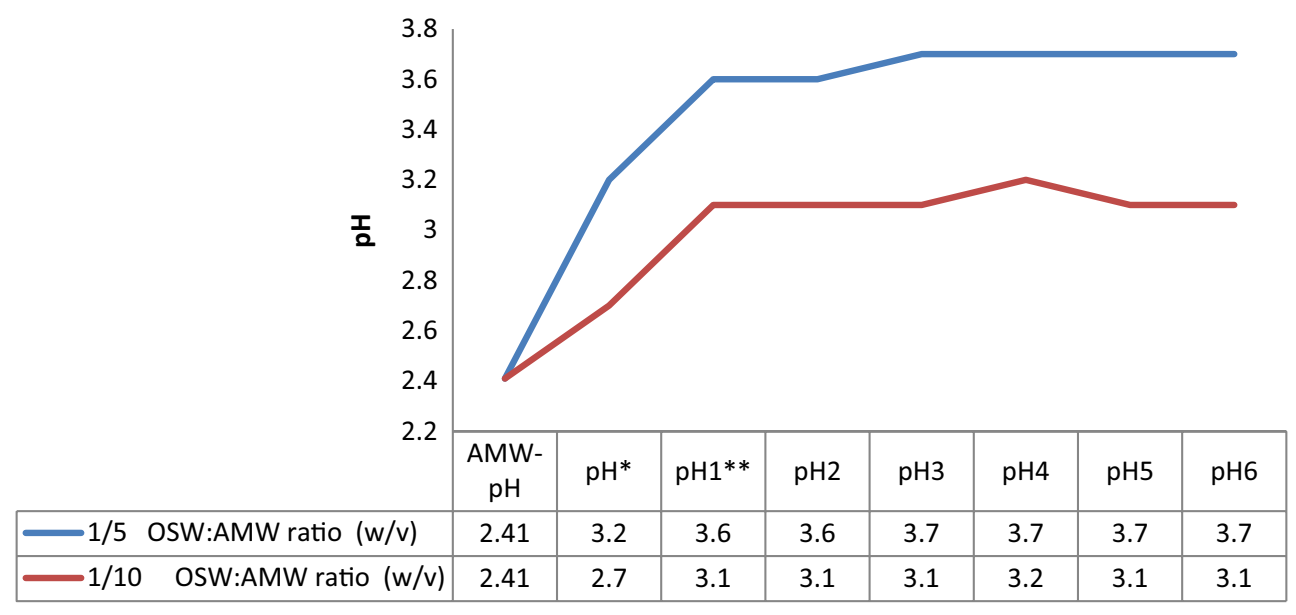

Fig. 3 Changes of $\mathrm{pH}$ as a function of time during the experiments (OSW:AMW mixture of $1 \mathrm{~g} / 5 \mathrm{ml}$ and $1 \mathrm{~g} / 10 \mathrm{ml}$ ) with starting $\mathrm{pH}$ AMW, interval among other $\mathrm{pH}$ readings were $1 \mathrm{~h}$ (last $\mathrm{pH}$ reading of 2.41 . $* 10 \mathrm{~min}$. after mixing, $* * 19.5 \mathrm{~h}$ after mixing of OSW and (pH6) was done $24.5 \mathrm{~h}$ after first reading)

Table 4 Descriptive statistics of metal/metalloids concentrations $\left(\mathrm{mg} \mathrm{L}^{-1}\right)$ in AMW:OSW mixtures

\begin{tabular}{llrrrrrr}
\hline $\begin{array}{l}\text { Metals and } \\
\text { metalloids }\end{array}$ & Applications & $N$ & \multicolumn{1}{l}{ Mean } & Std. error & Minimum & Maximum & Significant \\
\hline Al & AMW & 4 & 272.950 & 0.484 & 271 & 274 & $p<0.05$ \\
& AMW:OSW (1:5) & 4 & 150.750 & 21.800 & 112 & 210 & \\
As & AMW:OSW (1:10) & 5 & 236.400 & 3.326 & 229 & 248 & \\
& AMW & 4 & 0.103 & 0.001 & 0.100 & 0.100 & $p<0.05$ \\
& AMW:OSW (1:5) & 4 & 0.104 & 0.006 & 0.090 & 0.110 & \\
Fe & AMW:OSW (1:10) & 5 & 0.080 & 0.006 & 0.060 & 0.090 & \\
& AMW & 4 & 411.000 & 1.225 & 408.000 & 414.000 & $p<0.05$ \\
& AMW:OSW (1:5) & 4 & 61.950 & 6.989 & 50.900 & 80.200 & \\
Cd & AMW:OSW (1:10) & 5 & 108.200 & 2.709 & 102.000 & 115.000 & \\
& AMW & 4 & 0.033 & 0.000 & 0.030 & 0.030 & $p<0.05$ \\
& AMW:OSW (1:5) & 4 & 0.020 & 0.003 & 0.020 & 0.030 & \\
B & AMW:OSW (1:10) & 5 & 0.020 & 0.001 & 0.020 & 0.020 & \\
& AMW & 4 & 11.700 & 0.108 & 11.400 & 11.900 & $p<0.05$ \\
& AMW:OSW (1:5) & 4 & 7.908 & 0.646 & 6.660 & 9.640 & \\
Ti & AMW:OSW (1:10) & 5 & 4.366 & 0.049 & 4.200 & 4.490 & \\
& AMW & 4 & 0.037 & 0.001 & 0.040 & 0.040 & $p<0.05$ \\
& AMW:OSW (1:5) & 4 & 0.017 & 0.002 & 0.010 & 0.020 & \\
\hline & AMW:OSW (1:10) & 5 & 0.006 & 0.000 & 0.010 & 0.010 & \\
\hline
\end{tabular}

used as a biosorbent for heavy metal removal. Carboxylic and phenolic functional groups were responsible for the cation exchange capacity of carrot residue (Nasernejad et al. 2005). Pagnanelli et al. (2003) used olive solid waste biosorption of $\mathrm{Cu}, \mathrm{Pb}$ and $\mathrm{Cd}$. They concluded that carboxylic and phenolic groups were responsible for metal removal by a surface complexation mechanism. Therefore, OSW can be a promising, economic and easily available waste to clean AMW from metals and metalloids.

\section{Conclusion}

AMW-containing metals and metalloids have been sampled from Biga Peninsula, Çanakkale. Such water poses risk to the environment since they contain elevated concentrations of metals and metalloids. Evaluation of OSW for the metal and metalloid removal from AMW was studied. The results showed that it is possible for reclamation of AMW using olive solid waste. Results indicated that 
Table 5 Statistical data of multiple comparisons between groups

\begin{tabular}{|c|c|c|c|c|c|}
\hline $\begin{array}{l}\text { Heavy metals and } \\
\text { metalloids }\end{array}$ & $\begin{array}{l}\text { (I) } 1 \text { (AMW) } 2 \\
(1: 5) 3(1: 10)\end{array}$ & $\begin{array}{l}\text { (J) } 1 \text { (AMW) } 2 \\
(1: 5) 3(1: 10)\end{array}$ & Mean difference (I-J) & Std. error & Sig. \\
\hline \multirow[t]{6}{*}{$\mathrm{Al}$} & \multirow[t]{2}{*}{1.00} & 2.00 & $122.20000^{*}$ & 17.214 & 0.000 \\
\hline & & 3.00 & 36.550 & 16.331 & 0.147 \\
\hline & \multirow[t]{2}{*}{2.00} & 1.00 & $-122.20000^{*}$ & 17.214 & 0.000 \\
\hline & & 3.00 & $-85.65000^{*}$ & 16.331 & 0.001 \\
\hline & \multirow[t]{2}{*}{3.00} & 1.00 & -36.550 & 16.331 & 0.147 \\
\hline & & 2.00 & $85.65000^{*}$ & 16.331 & 0.001 \\
\hline \multirow[t]{6}{*}{ As } & \multirow[t]{2}{*}{1.00} & 2.00 & -0.001 & 0.008 & 1.000 \\
\hline & & 3.00 & $0.02322 *$ & 0.007 & 0.028 \\
\hline & \multirow[t]{2}{*}{2.00} & 1.00 & 0.001 & 0.008 & 1.000 \\
\hline & & 3.00 & $0.02416 *$ & 0.007 & 0.023 \\
\hline & \multirow[t]{2}{*}{3.00} & 1.00 & $-0.02322^{*}$ & 0.007 & 0.028 \\
\hline & & 2.00 & $-.02416^{*}$ & 0.007 & 0.023 \\
\hline \multirow[t]{6}{*}{$\mathrm{Fe}$} & \multirow[t]{2}{*}{1.00} & 2.00 & $349.05000^{*}$ & 6.128 & 0.000 \\
\hline & & 3.00 & $302.80000^{*}$ & 5.813 & 0.000 \\
\hline & \multirow[t]{2}{*}{2.00} & 1.00 & $-349.05000^{*}$ & 6.128 & 0.000 \\
\hline & & 3.00 & $-46.25000^{*}$ & 5.813 & 0.000 \\
\hline & \multirow[t]{2}{*}{3.00} & 1.00 & $-302.80000^{*}$ & 5.813 & 0.000 \\
\hline & & 2.00 & $46.25000^{*}$ & 5.813 & 0.000 \\
\hline \multirow[t]{6}{*}{$\mathrm{Cd}$} & \multirow[t]{2}{*}{1.00} & 2.00 & $0.01267 *$ & 0.003 & 0.002 \\
\hline & & 3.00 & $0.01261 *$ & 0.002 & 0.001 \\
\hline & \multirow[t]{2}{*}{2.00} & 1.00 & $-0.01267 *$ & 0.003 & 0.002 \\
\hline & & 3.00 & 0.000 & 0.002 & 1.000 \\
\hline & \multirow[t]{2}{*}{3.00} & 1.00 & $-0.01261^{*}$ & 0.002 & 0.001 \\
\hline & & 2.00 & 0.000 & 0.002 & 1.000 \\
\hline \multirow[t]{6}{*}{ B } & \multirow[t]{2}{*}{1.00} & 2.00 & $3.79250 *$ & 0.509 & 0.000 \\
\hline & & 3.00 & $7.33400^{*}$ & 0.483 & 0.000 \\
\hline & \multirow[t]{2}{*}{2.00} & 1.00 & $-3.79250^{*}$ & 0.509 & 0.000 \\
\hline & & 3.00 & $3.54150^{*}$ & 0.483 & 0.000 \\
\hline & \multirow[t]{2}{*}{3.00} & 1.00 & $-7.33400^{*}$ & 0.483 & 0.000 \\
\hline & & 2.00 & $-3.54150^{*}$ & 0.483 & 0.000 \\
\hline \multirow[t]{6}{*}{$\mathrm{Ti}$} & \multirow[t]{2}{*}{1.00} & 2.00 & $0.02033^{*}$ & 0.002 & 0.000 \\
\hline & & 3.00 & $0.03067 *$ & 0.002 & 0.000 \\
\hline & \multirow[t]{2}{*}{2.00} & 1.00 & $-0.02033^{*}$ & 0.002 & 0.000 \\
\hline & & 3.00 & 0.01035* & 0.002 & 0.001 \\
\hline & \multirow[t]{2}{*}{3.00} & 1.00 & $-0.03067 *$ & 0.002 & 0.000 \\
\hline & & 2.00 & $-0.01035^{*}$ & 0.002 & 0.001 \\
\hline
\end{tabular}

*The mean difference is significant at the 0.05 level mixing OSW with AMW at different rates reduced $\mathrm{Al}$, As, Cd, Fe, Ti and B concentrations of water. Results suggested that OSW can remove maximum of $764 \mathrm{mg} \mathrm{g}^{-1}$ of $\mathrm{Al}, 0.14 \mathrm{mg} \mathrm{g}^{-1} \mathrm{Cd}, 3406.5 \mathrm{mg} \mathrm{g}^{-1} \mathrm{Fe}, 82.5 \mathrm{mg} \mathrm{g}^{-1} \mathrm{~B}$ and $0.35 \mathrm{mg} \mathrm{g}^{-1} \mathrm{Ti}$ from AMW. OSW removed Fe more efficiently than other cations with a removal percentage approximately equal to $85 \%$. Using raw OSW is an alternative method to remove metals and metalloids from AMW. OSW is easily reachable and inexpensive waste material in the Region. Therefore, it can be used easily and quickly in need. 

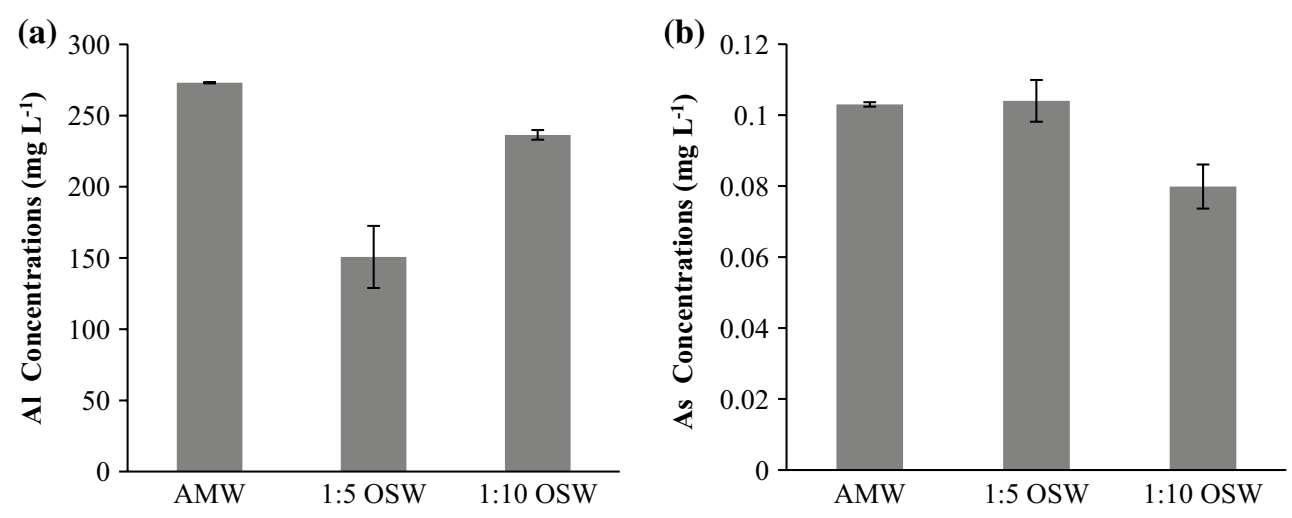

Fig. 4 a, b Al and As concentrations of AMW after OSW treatment
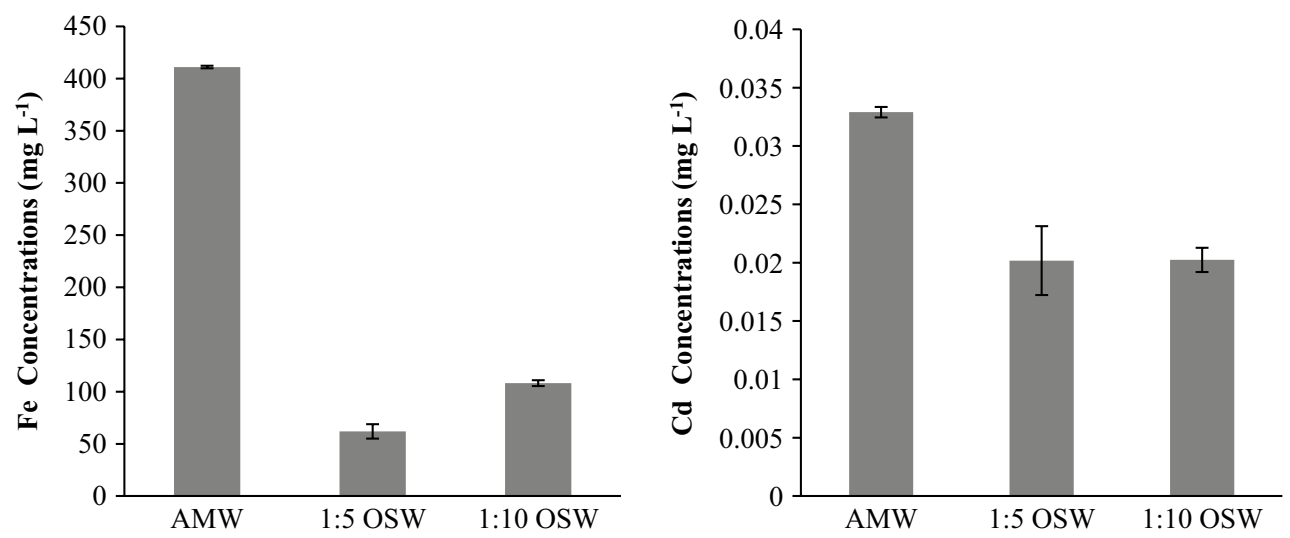

Fig. 5 a, b Fe and Cd concentrations of AMW before and after OSW treatment

Fig. 6 a, b B and Ti concentrations of AMW after OSW treatment

Table 6 Heavy metals and metalloids adsorption capacities $\left(\mathrm{mg} \mathrm{g}^{-1}\right)$ of OSW
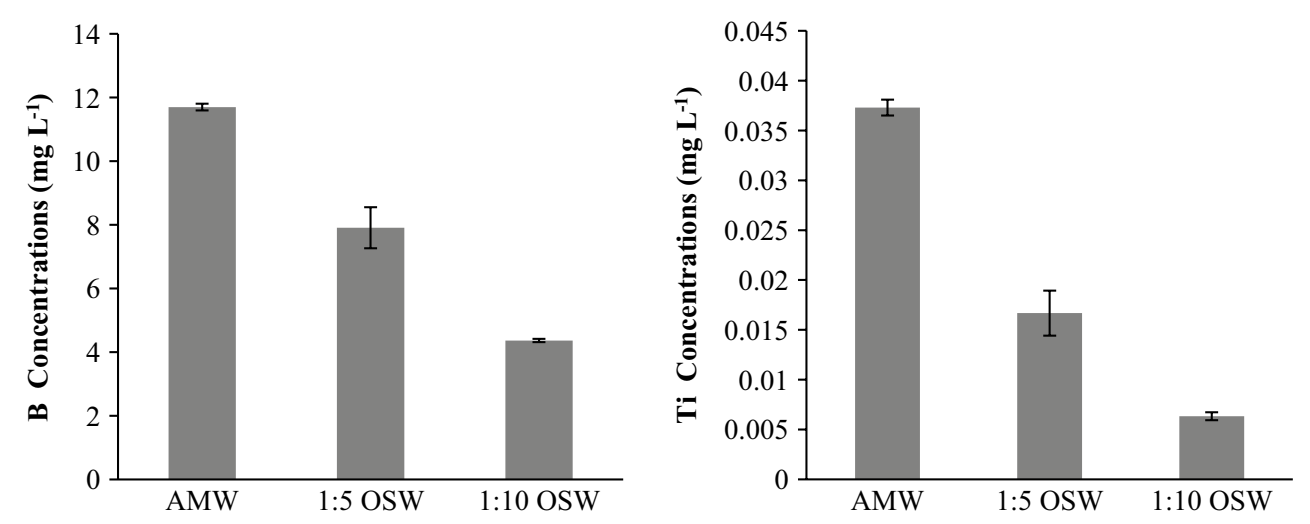

\begin{tabular}{lllllll}
\hline $\begin{array}{l}\text { OSW:AMW ratio } \\
(\mathrm{w} / \mathrm{v})\end{array}$ & $\mathrm{Al}$ & $\mathrm{As}$ & $\mathrm{Cd}$ & $\mathrm{Fe}$ & $\mathrm{B}$ & $\mathrm{Ti}$ \\
\hline $1: 5$ & 764.06 & - & 0.079 & 2181.56 & 23.703 & 0.128 \\
$1: 10$ & 411.75 & 0.260 & 0.142 & 3406.5 & 82.507 & 0.348 \\
\hline
\end{tabular}


Acknowledgments The authors wish to thank all who assisted in conducting this work.

\section{Compliance with ethical standards}

Conflict of interest The authors declare that they have no conflict of interest.

\section{References}

Abollino O, Aceto M, Malandrino M et al (2003) Adsorption of heavy metals on Na-montmorillonite. Effect of $\mathrm{pH}$ and organic substances. Water Res 37:1619-1627. https://doi.org/10.1016/s0043 -1354(02)00524-9

Abu Al-Rub FA (2006) Biosorption of zinc on palm tree leaves: equilibrium, kinetics, and thermodynamics studies. Sep Sci Technol 41:3499-3515. https://doi.org/10.1080/01496390600915015

Ajmal M, Rao R, Ahmad R, Ahmad J (2000) Adsorption studies on Citrus reticulata (fruit peel of orange): removal and recovery of $\mathrm{Ni}$ (II) from electroplating wastewater. J Hazard Mater B79:117-131. https://doi.org/10.1016/S0304-3894(00)00234-X

Al-Anber ZA, Matouq MAD (2008) Batch adsorption of cadmium ions from aqueous solution by means of olive cake. J Hazard Mater 151:194-201. https://doi.org/10.1016/j.jhazmat.2007.05.069

Ali I (2010) The quest for active carbon adsorbent substitutes, inexpensive adsorbents for toxic metal ions removal from wastewater. Sep Purif Rev 39:95-171. https://doi.org/10.1080/15422 119.2010 .527802

Ali I (2012) New generation adsorbents for water treatment. Chem Rev 112(10):5073-5091. https://doi.org/10.1021/cr300133d

Ali I, Asim M, Khan TA (2012) Low cost adsorbents for the removal of organic pollutants from wastewater. J Environ Manag 113:170 183. https://doi.org/10.1016/j.jenvman.2012.08.028

Ali I, Alothman ZA, Alwarthan A (2016) Synthesis of composite iron nano adsorbent and removal of ibuprofen drug residue from water. J Mol Liq 219:858-864. https://doi.org/10.1016/j.molli q.2016.04.031

Ali I, Alothman ZA, Alwarthan A (2017) Uptake of propranolol on ionic liquid iron nanocomposite adsorbent: kinetic, thermodynamics and mechanism of adsorption. J Mol Liq 236:205-213. https ://doi.org/10.1016/j.molliq.2017.04.028

Amin N, Kaneco S, Kitagawa T, Begum A, Katsumata H, Suzuki T, Ohta K (2006) Removal of arsenic in aqueous solutions by adsorption onto waste rice husk. Ind Eng Chem Res 45:8105-8110. https ://doi.org/10.1021/ie060344j

Andini S, Cioffi R, Montagnaro F, Pisciotta F, Santo L (2006) Simultaneous adsorption of chlorophenol and heavy metal ions on organophilic bentonite. Appl Clay Sci 31:126-133. https://doi. org/10.1016/j.clay.2005.09.004

Baba A, Gunduz O (2010) Effect of alteration zones on water quality: a case study from Biga peninsula, Turkey. Arch Environ Contam Toxicol 58:499-513. https://doi.org/10.1007/s00244-009-9406-8

Baba A, Save D, Gündüz O, Gürdal G, Bozcu M, Sülün S, Özcan HO, Hayran, H. İkiışık, L. Bakırcı (2009) Effect of mining activity on human health. TÜBİTAK Project, Türkiye Bilimsel ve Teknik Araştırma Kurumu (TÜBİTAK) Project No: ÇAYDAG-106Y041, Ankara (in Turkish)

Balarak D, Jaafari J, Hassani G, Mahdavi Y, Tyagi I, Agarwal S, Gupta VK (2015) The use of low-cost adsorbent (Canola residues) for the adsorption of methylene blue from aqueous solution: 1sotherm, kinetic and thermodynamic studies. Colloids Interface Sci Commun 7:16-19. https://doi.org/10.1016/j.colcom.2015.11.004
Bechard G (1993) Microbiological process for the treatment of acid mine drainage using cellulosic substrates. Ph.D. Thesis; Department of Biology; Carleton University

Blodau C (2006) A review of acidity generation and consumption in acidic coal mine lakes and their watersheds. Sci Total Environ 369:307-332. https://doi.org/10.1016/j.scitotenv.2006.05.004

Can C, Jianlong W (2008) Investigating the interaction mechanism between zinc and Saccharomyces cerevisiae using combined SEM-EDX and XAFS. Appl Microbiol Biotechnol 79:293-299. https://doi.org/10.1007/s00253-008-1415-4

Chuang CL, Fan M, Xu M, Brown RC, Sung S, Saha B, Huang CP (2005) Adsorption of arsenic (V) by activated carbon prepared from oat hulls. Chemosphere 61(4):478-483. https://doi. org/10.1016/j.chemosphere.2005.03.012

Demirbas E, Kobya M, Oncel S, Sencan S (2002) Removal of Ni(II) from aqueous solution by adsorption onto hazelnut shell activated carbon: equilibrium studies. Bioresour Technol 84(3):291-293. https://doi.org/10.1016/s0960-8524(02)00052-4

Escudero C, Gabaldón C, Marzal P, Villaescusa I (2008) Effect of EDTA on divalent metal adsorption onto grape stalk and exhausted coffee wastes. J Hazard Mater 152:476-485. https:// doi.org/10.1016/j.jhazmat.2007.07.013

Evangelou VP (1998) Pyrite oxidation control. In: Geller W, Klapper $\mathrm{H}$, Salomons W (eds) Acidic mining lakes-acid mine drainage", limnology and reclamation. Springer, Berlin, pp 419-421

Farinella NV, Matos GD, Arruda MAZ (2007) Grape bagasse as a potential biosorbent of metals in effluent treatments. Bioresour Technol 98(10):1940-1946. https://doi.org/10.1016/j.biort ech.2006.07.043

Friese K, Hupfer M, Shultze M (1998) Chemical characteristics of water and sediment in acidic mining lakes of the Lusatian Lignite District. In: Geller W, Klapper H, Salomons W (eds) Acidic mining lakes-acid mine drainage, limnology and reclamation. Springer, Berlin, pp 25-45

Gaballah I, Kilbertus G (1998) Recovery of heavy metal ions through decontamination of synthetic solutions and industrial effluents using modified barks. J Geochem Explor 62:241-286. https:// doi.org/10.1016/s0375-6742(97)00068-x

Gardea-Torresdey JL, Tang L, Salvador JM (1996) Copper adsorption by esterified and unesterified fractions of Sphagnum peat moss and its different humic substances. J Hazard Mater 48:191-206. https://doi.org/10.1016/0304-3894(95)00156-5

Geller W, Klapper H, Schultze M (1998) Natural and anthropogenic sulfuric acidification of lakes. In: Geller W, Klapper H, Salomons W (eds) Acidic mining lakes-adic mine drainage, limnology and reclamation. Springer, Berlin, pp 3-14

General Directorate of Mineral Research, Exploration (2002) Geological map of Turkey, scale 1:500.000. MTA, Ankara

Gharaibeh SH, Abu-El-Sha'r WY, Al-Kofahi MM (1998) Removal of selected heavy metals from aqueous solutions using processed solid residue of olive mill products. Water Res 32:498-502. https://doi.org/10.1016/s0043-1354(97)00221-2

Gunduz O, Baba A (2008) Fate of acidic mining lakes in Can Lignite District, Turkey. In: Proceedings of the XXXVI IAH congress integrating groundwater science and human well-being proceedings CD-ROM., October, Toyama, Japan

Gunduz O, Okumusoglu D, Baba A (2007) Acidic mining lakes and their influence on water quality: a case study from Can (Canakkale), Turkey. In: Proceedings of the 6th International groundwater quality conference GQ07: securing groundwater quality in urban and Industrial environments, Fremantle, Western Australia. ISBN: 978-0-643-095519

Gupta VK, Saleh TA (2013) Sorption of pollutants by porous carbon, carbon nanotubes and fullerene-an overview. Environ Sci Pollut Res 20(5):2828-2843. https://doi.org/10.1007/s1135 6-013-1524-1 
Gupta VK, Srivastava SK, Mohan D, Sharma S (1998) Design parameters for fixed bed reactors of activated carbon developed from fertilizer waste for the removal of some heavy metal ions. Waste Manag 17(8):517-522. https://doi.org/10.1016/s0956 $-053 \times(97) 10062-9$

Gupta VK, Rastogi A, Saini VK, Jain N (2006) Biosorption of copper(II) from aqueous solutions by Spirogyra species. J Colloid Interface Sci 296:59-63. https://doi.org/10.1016/j. jcis.2005.08.033

Gupta VK, Agarwal S, Saleh TA (2011) Synthesis and characterization of alumina-coated carbon nanotubes and their application for lead removal. J Hazard Mater 185(1):17-23. https://doi. org/10.1016/j.jhazmat.2010.08.053

Gupta VK, Jain R, Mittal A, Saleh TA, Nayak A, Agarwal S, Sikarwar S (2012a) Photo-catalytic degradation of toxic dye amaranth on $\mathrm{TiO}_{2} / \mathrm{UV}$ in aqueous suspensions. Mater Sci Eng, C 32(1):12-17. https://doi.org/10.1016/j.msec.2011.08.018

Gupta VK, Ali I, Saleh TA, Nayak A, Agarwal S (2012b) Chemical treatment technologies for waste-water recycling-an overview. RSC Adv 2(16):6380-6388. https://doi.org/10.1039/c2ra20340e

Gupta VK, Kumar R, Nayak A, Saleh TA, Barakat MA (2013) Adsorptive removal of dyes from aqueous solution onto carbon nanotubes: a review. Adv Colloid Interface Sci 193:24-34. https://doi. org/10.1016/j.cis.2013.03.003

Hamza IA, Martincigh BS, Ngila JC, Nyamori VO (2013) Adsorption studies of aqueous $\mathrm{Pb}$ (II) onto a sugarcane bagasse/multiwalled carbon nanotube composite. Phys Chem Earth Parts A/B/C 66:157-166. https://doi.org/10.1016/j.pce.2013.08.006

Hasan S, Hashim MA, Sen Gupta B (2000) Adsorption of Ni( $\left.\mathrm{SO}_{4}\right)$ on Malaysian rubber-wood ash. Bioresour Technol 72:153-158. https ://doi.org/10.1016/s0960-8524(99)00101-7

Hegazi HA (2013) Removal of heavy metals from wastewater using agricultural and industrial wastes as adsorbents. HBRC J 9(3):276-282. https://doi.org/10.1016/j.hbrcj.2013.08.004

İlay R, Kavdir Y, Sümer A (2013) The effect of olive oil solid waste application on soil properties and growth of sunflower (Helianthus annuus L.) and bean (Phaseolus vulgaris L.). Int Biodeterior Biodegrad 85:254-259. https://doi.org/10.1016/j.ibiod.2013.07.008

Iqwe JC, Ogunewe DN, Abia AA (2005) Competitive adsorption of Zn (II), $\mathrm{Cd}$ (II) and $\mathrm{Pb}$ (II) ions from aqueous and non-aqueous solution by maize cob and husk. Afr J Biotechnol 4(10):1113-1116

Kadirvelu K, Thamaraiselvi K, Namasivayam C (2001) Removal of heavy metals from industrial wastewaters by adsorption onto activated carbon prepared from an agricultural solid waste. Bioresour Technol 76(1):63-65. https://doi.org/10.1016/S0960 -8524(00)00072-9

Kaikake K, Hoaki K, Sunada H et al (2007) Removal characteristics of metal ions using degreased coffee beans: adsorption equilibrium of cadmium(II). Bioresour Technol 98:2787-2791. https://doi. org/10.1016/j.biortech.2006.02.040

Karakas G, Brookland I, Boehrer B (2003) Physical characteristics of acidic mining lake 111. Aquat Sci 65:297-307. https://doi. org/10.1007/s00027-003-0651-z

Kelly-Vargas K, Cerro-Lopez M, Reyna-Tellez S, Bandala ER, Sanchez-Salas JL (2012) Biosorption of heavy metals in polluted water, using different waste fruit cortex. Phys Chem Earth Parts A/B/C 37:26-29. https://doi.org/10.1016/j.pce.2011.03.006

Khan TA, Sharma S, Ali I (2011) Adsorption of Rhodamine B dye from aqueous solution onto acid activated mango (Magnifera indica) leaf powder: equilibrium, kinetic and thermodynamic studies. J Toxicol Environ Health Sci 3:286-297

Kirsten W (1983) Organic elemental analysis: ultramicro, micro, and trace methods. Academic Press, Harcourt Brace Jovanovich, New York

Kurniawan TA, Chan GY, Lo WH, Babel S (2006) Comparisons of lowcost adsorbents for treating wastewaters laden with heavy metals.
Sci Total Environ 366(2):409-426. https://doi.org/10.1016/j.scito tenv.2005.10.001

Lee SH, Jung CH, Chung H, Lee MY, Yang JW (1998) Removal of heavy metals from aqueous solution by apple residues. Process Biochem 33(2):205-211. https://doi.org/10.1016/s0032 -9592(97)00055-1

Lesage-Meessen L, Navarro D, Maunier S, Sigoillot JC, Lorquin J, Delattre $\mathrm{M}$ et al (2001) Simple phenolic content in olive oil residues as a function of extraction systems. Food Chem 75:501-507. https://doi.org/10.1016/s0308-8146(01)00227-8

Liu R, Ma W, Jia CY, Wang L, Li HY (2007) Effect of pH on biosorption of boron onto cotton cellulose. Desalination 207(1-3):257267. https://doi.org/10.1016/j.desal.2006.07.012

López-Mesas M, Navarrete ER, Carrillo F, Palet C (2011) Bioseparation of $\mathrm{Pb}$ (II) and $\mathrm{Cd}$ (II) from aqueous solution using cork waste biomass. Modeling and optimization of the parameters of the biosorption step. Chem Eng J 174(1):9-17. https://doi. org/10.1016/j.cej.2011.07.026

Malkoc E, Nuhoglu Y (2007) Potential of tea factory waste for chromium (VI) removal from aqueous solutions: thermodynamic and kinetic studies. Sep Purif Technol 54(3):291-298. https://doi. org/10.1016/j.seppur.2006.09.017

Martinez M, Miralles N, Hidalgo S, Fiol N, Villaescusa I, Poch J (2006) Removal of lead(II) and cadmium(II) from aqueous solutions using grape stalk waste. J Hazard Mater 133:203-211. https ://doi.org/10.1016/j.jhazmat.2005.10.030

Martín-Lara MA, Pagnanelli F, Mainelli S, Calero M, Toro L (2008) Chemical treatment of olive pomace: effect on acid-basic properties and metal biosorption capacity. J Hazard Mater 156:448-457. https://doi.org/10.1016/j.jhazmat.2007.12.035

MEND (1994) Canada-wide survey of acid mine drainage characteristics; Canada Center for Mineral and Energy Technology (CANMET); MEND Project 3.22.1

Meunier N, Laroulandie J, Blais JF, Tyagi RD (2003) Cocoa shells for heavy metal removal from acidic solutions. Bioresour Technol 90:255-263. https://doi.org/10.1016/s0960-8524(03)00129-9

Mittal A, Mittal J, Malviya A, Gupta VK (2009) Adsorptive removal of hazardous anionic dye "Congo red" from wastewater using waste materials and recovery by desorption. J Colloid Interface Sci 340(1):16-26. https://doi.org/10.1016/j.jcis.2009.08.019

Mittal A, Mittal J, Malviya A, Gupta VK (2010) Removal and recovery of Chrysoidine $\mathrm{Y}$ from aqueous solutions by waste materials. J Colloid Interface Sci 344(2):497-507. https://doi.org/10.1016/j. jcis.2010.01.007

Nadaroglu H, Kalkan E, Demir N (2010) Removal of copper from aqueous solution using red mud. Desalination 251:90-95. https ://doi.org/10.1016/j.desal.2009.09.138

Naiya TK, Bhattacharya AK, Mandal S, Das SK (2009) Adsorption of $\mathrm{Zn}(\mathrm{II}), \mathrm{Cd}(\mathrm{II})$ and $\mathrm{Pb}(\mathrm{II})$ onto fly ash. In: Shengcai L, Yajun W, Fengxia C, Ping H, Yao Z (eds) Progress in environmental science and technology, vol 2. Science Press, Monmouth Junction, pp 2041-2051

Nasernejad B, Zadeh TE, Pour BB, Bygi ME, Zamani A (2005) Camparison for biosorption modeling of heavy metals $(\mathrm{Cr}(\mathrm{III}), \mathrm{Cu}$ (II), Zn (II)) adsorption from wastewater by carrot residues. Process Biochem 40:1319-1322. https://doi.org/10.1016/j.procb io.2004.06.010

Oztürk N, Kavak D (2005) Adsorption of boron from aqueous solutions using fly ash: batch and column studies. J Hazard Mater 127:81-88. https://doi.org/10.1016/j.jhazmat.2005.06.026

Pagnanelli F, Mainelli S, Vegliò F, Toro L (2003) Heavy metal removal by olive pomace: biosorbent characterisation and equilibrium modelling. Chem Eng Sci 58(20):4709-4717. https://doi. org/10.1016/j.ces.2003.08.001 
Periasamy K, Namasivayam C (1996) Removal of copper(II) by adsorption onto peanut hull carbon from water and copper plating industry wastewater. Chemosphere 32(4):769-789. https://doi. org/10.1016/0045-6535(95)00332-0

Qi BC, Aldrich C (2008) Biosorption of heavy metals from aqueous solutions with tobacco dust. Bioresour Technol 99(13):55955601. https://doi.org/10.1016/j.biortech.2007.10.042

Reddad Z, Gérente C, Andrès Y et al (2003) Cadmium and lead adsorption by a natural polysaccharide in MF membrane reactor: experimental analysis and modelling. Water Res 37:3983-3991. https:// doi.org/10.1016/s0043-1354(03)00295-1

Report 1.20.1. December. http://www.fs.usda.gov/Internet/FSE_ DOCUMENTS/stelprdb5336546.pdf

Saravanan R, Shankar H, Prakash T, Narayanan V, Stephen A (2011) $\mathrm{ZnO} / \mathrm{CdO}$ composite nanorods for photocatalytic degradation of methylene blue under visible light. Mater Chem Phys 125(1):277280. https://doi.org/10.1016/j.matchemphys.2010.09.030

Saravanan R, Gupta VK, Narayanan V, Stephen A (2013a) Comparative study on photocatalytic activity of $\mathrm{ZnO}$ prepared by different methods. J Mol Liq 181:133-141. https://doi.org/10.1016/j.molli q.2013.02.023

Saravanan R, Thirumal E, Gupta VK, Narayanan V, Stephen A (2013b) The photocatalytic activity of $\mathrm{ZnO}$ prepared by simple thermal decomposition method at various temperatures. J Mol Liq 177:394-401. https://doi.org/10.1016/j.molliq.2012.10.018

Saravanan R, Gracia F, Khan MM, Poornima V, Gupta VK, Narayanan $\mathrm{V}$, Stephen A (2015) $\mathrm{ZnO} / \mathrm{CdO}$ nanocomposites for textile effluent degradation and electrochemical detection. J Mol Liq 209:374380. https://doi.org/10.1016/j.molliq.2015.05.040

Saravanan R, Sacari E, Gracia F, Khan MM, Mosquera E, Gupta VK (2016) Conducting PANI stimulated $\mathrm{ZnO}$ system for visible light photocatalytic degradation of coloured dyes. J Mol Liq 221:10291033. https://doi.org/10.1016/j.molliq.2016.06.074

Schultze M, Geller W (1996) The acid lakes of lignite mining district of the former German Democratic Republic. In: Reuther R (ed) Geochemical approaches to environmental engineering of metals. Springer, Berlin; Heidelberg; New York, pp 89-105. ISBN 3-540-58848-5

Sun G, Shi W (1998) Sunflower stalks as adsorbents for the removal of metal 1ons from wastewater. Ind Eng Chem Res 37:1324-1328. https://doi.org/10.1021/ie970468j

TUIK (2015) Turkish Statistical Institute. http://www.tuik.gov.tr/PreIs tatistikTablo.do?istab_id=1073. Accesed 02 June 2016

Veglio F, Beolchini F (1997) Removal of metals by biosorption: a review. Hydrometallurgy 44(3):301-316. https://doi.org/10.1016/ s0304-386x(96)00059-x

Vijayaraghavan K, Palanivelu K, Velan M (2006) Biosorption of copper(II) and cobalt(II) from aqueous solutions by crab shell particles. Bioresour Technol 97:1411-1419. https://doi. org/10.1016/j.biortech.2005.07.001

Vile MA, Wieder RK (1993) Alkalinity generation by $\{\mathrm{Fe}\}(\{\mathrm{III}\})$ reduction versus sulfate reduction in wetlands constructed for acid mine drainage treatment. Water Air Soil Pollut 69:425-441

Villaescusa I, Fiol N, Martinez M et al (2004) Removal of cooper and nickel ions from aqueous solutions by grape stalks wastes. Water Res 38:992-1002

Wang XS, Qin Y, Li Z-F (2006) Biosorption of zinc from aqueous solutions by rice bran: kinetics and equilibrium studies. Sep Sci Technol 41:747-756. https://doi.org/10.1080/01496390500527951

Wang XS, Li ZZ, Tao SR (2009) Removal of chromium (VI) from aqueous solution using walnut hull. J Environ Manag 90:721-729. https://doi.org/10.1016/j.jenvman.2008.01.011

Weng CH, Huang CP (2004) Adsorption characteristics of Zn(II) from dilute aqueous solution by fly ash. Colloids Surf A Physicochem Eng Asp 247:137-143. https://doi.org/10.1016/j.colsu rfa.2004.08.050

Wisotzky F, Obermann P (2001) Acid mine groundwater in lignite overburden dumps and its prevention-the Rhineland lignite mining area (Germany). Ecol Eng. https://doi.org/10.1016/s0925 -8574(00)00152-x

Wolf A, Watson M, Wolf N (2003) Digestion and dissolution methods for P, K, Ca, Mg and trace elements. In: Peters J (ed) Recommended methods of manure analysis, vol A3769. University of Wisconsin Extension Publication, Madison, pp 30, 32-35

Yucel DS, Baba A (2013) Geochemical characterization of acid mine lakes in northwest turkey and their effect on the environment. Arch Environ Contam Toxicol 64:357-376. https://doi. org/10.1007/s00244-012-9843-7

Yucel DS, Baba A (2016) Prediction of acid mine drainage generation potential of various lithologies using static tests: Etili coal mine (NW Turkey) as a case study. Environ Monit Assess 188:473. https://doi.org/10.1007/s10661-016-5462-5

Yucel DS, Yucel MA, Baba A (2014) Change detection and visualization of acid mine lakes using time series satellite image data in geographic information systems (GIS): Can (Canakkale) County, NW Turkey. Environ Earth Sci. https://doi.org/10.1007/s1266 5-014-3330-6

Yucel DS, Balc1 N, Baba A (2016) Generation of acid mine lakes associated with abandoned coal mines in Northwest Turkey. Arch Environ Contam Toxicol 70:757-782. https://doi.org/10.1007/ s00244-016-0270-Z

Zhou X, Korenaga T, Takahashi T, Moriwake T, Shinoda S (1993) A process monitoring/controlling system for the treatment of wastewater containing chromium (VI). Water Res 27:1049-1054. https ://doi.org/10.1016/0043-1354(93)90069-t 